\title{
Philogelos 63 and the Meaning of $\grave{\varepsilon} \omega \alpha^{*}$
}

\author{
Vsevolod V.Zeltchenko
}

St. Petersburg State University, 7-9, Universitetskaya nab., St. Petersburg, 199034, Russian Federation; v.zelchenko@spbu.ru

For citation: Vsevolod V. Zeltchenko. Philogelos 63 and the Meaning of éẃpa. Philologia Classica 2019, 14 (2), 310-317. https://doi.org/10.21638/11701/spbu20.2019.210

In an unassuming story 63 from the Philogelos collection, a one-eyed governor goes cic ċúpav, praising to his companion "the grapevines on the left side (of the road)". A set of attested

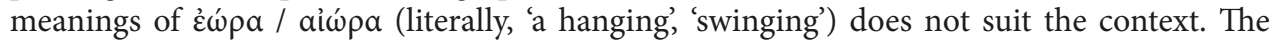
story is extant only in a longer variant of the collection; its first editor, J. F. Boissonade (1848), supposed that $\dot{\varepsilon} \omega$ pa in this context means 'grapes suspended from trees. The successive commentators and translators, having accepted his idea, understand it as 'a vineyard'; meanwhile, the Greek lexicons, from LSJ to F. Montanari, have ignored both Boissonade's interpretation and the passage itself. The article stresses that Boissonade profited from an unmentioned gloss of G. Wakefield, surviving in the London (1821) and Parisian (1831) revisions of Thesaurus Graecae Linguae of Henri Estienne, as well as from the glossed passage Suda a 261 Adler itself (a schoolroom interpolation in the text of Babr. 19). While in Ps.-Babrius the word is used in its common meaning ('something hanging'), in the context of Philog. 63 one expects rather a statement of the purpose of the governor's outing: the words "when he went out into the vineyard", lacking any explanation whatever, make an ex abrupto beginning. Dismissing the interpretation of Boissonade, the author draws attention to the fact that in writers of

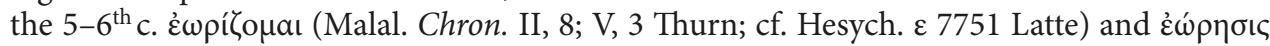
(Ioseph. Hypomn. 46) are attested in the meanings 'to take a walk' and 'a walk' resp.; the same meaning should be supposed for $\dot{\varepsilon} \omega \rho \alpha$ in Philog. 63. In all probability, the semantic shift from

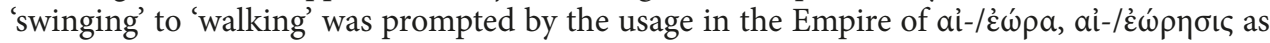
equivalents to the Latin gestatio - a therapeutic practice of a mild agitation of the patient's body (be it in a carriage, a litter, on board a ship, or in a hammock). Medical prescriptions of doctors and literary works of their clients alike mention gestatio alongside walking, which may have contributed to a broadening of respective units.

Keywords: Philogelos, ṡẃpa, gestatio, Ancient Greek lexicology, Ancient Greek lexicography.

* We are grateful to Tatiana Kostyleva for an English translation.

(C) St. Petersburg State University, 2019 


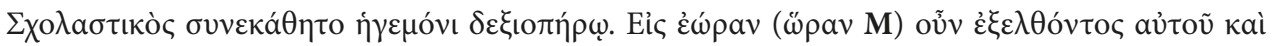

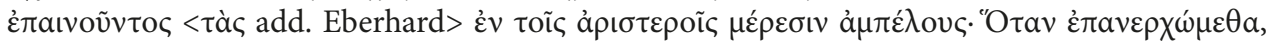

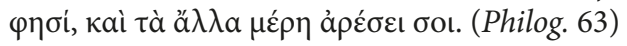

"A scholastikos was serving as an assessor to a provincial governor who was blind in the right

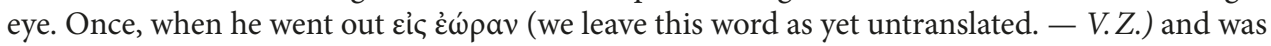
praising the grapevines to his left, scholastikos said, 'On our way back, you will be pleased with the opposite side as well" ".

The point of the story is clear: fawning on his superior, an obsequious underling

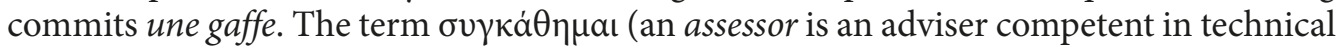
points of law and court procedure sitting as assistant to a provincial governor) was misinterpreted in the influential edition of Alfred Eberhard, ${ }^{1}$ to be later set aright by Andreas Thierfelder. ${ }^{2}$ Our lot is thus the leftover piece $\varepsilon \dot{\omega} \rho \alpha$ which has not yet, unlike the other unicum $\delta \varepsilon \xi$ เó $п \rho о$ (v. infra), had its due.

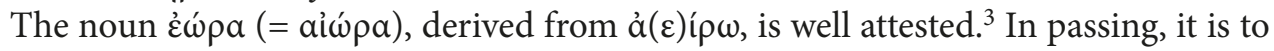
be stressed that the initial $\dot{\varepsilon}$-, though a solecism often enough, was spun up by the learned speculations of the grammarians of the Empire, who saw in $\dot{\varepsilon} \omega \rho \alpha$ the true Attic spell-

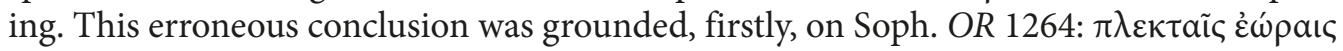
$\dot{\varepsilon} \mu \pi \varepsilon \pi \lambda \varepsilon \gamma \mu \varepsilon \dot{v} \eta \nu \cdot$ ó $\delta \varepsilon \dot{. . . ~(w h e r e ~ a i ̂ ́ p a ı ৎ ~ w o u l d ~ b e ~ u n m e t r i c a l), ~ a n d ~ s e c o n d l y, ~ o n ~ t h e ~ a d j e c-~}$

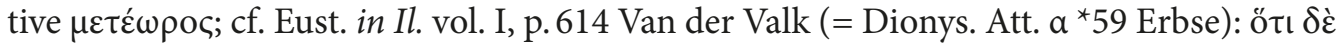

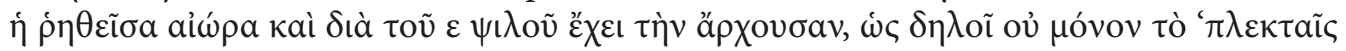

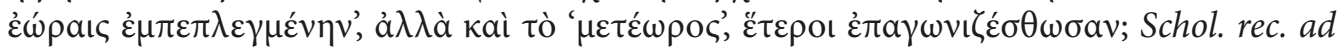

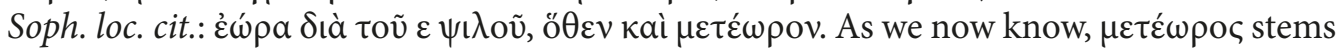
from $\mu \varepsilon \tau$ ๆ́o $о$, , while the Sophoclean passage is corrupt, since "the alternation of al with $\varepsilon$ is impossible before the first or second century $\mathrm{AD}$, and even then could be used only by a vulgar writer"; ${ }^{4}$ however, due to its 'philological' origin, the $\dot{\varepsilon} \omega \rho$ - deserves, in our opinion, more care on part of the editors. ${ }^{5}$

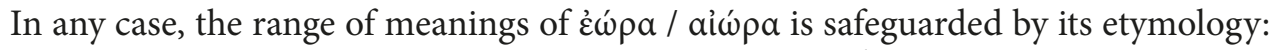
from the abstract 'hanging, 'elevation', 'oscillatory movement'6 to concrete 'halter', 'swing' and 'hammock', - none of which is relevant for our passage.

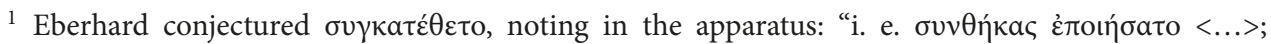
oportebat saltem dici $\sigma v v \varepsilon \beta a \dot{\alpha} \delta \zeta \varepsilon^{\prime \prime}$ (Eberhard 1869, 19). The misunderstanding made its way into a number of translations (e. g., "A pedant went to walk with a guide...": Bubb 1920, 34; "Mędrek jechał razem ze ślepym na prawe oko namiestnikiem...": Łanowski 1986, 31; "Un sapientone sedeva accanto da un conducente...": Vergara 2011, 84 and n.) and a recent book by Anna Tarwacka - who, specifically discussing the legal vocabulary of the Philogelos, quotes story 63 according to Lanowski and, thus, misses out an assessor altogether (Tarwacka 2016, 45).

2 Thierfelder 1968, 221. On the meaning of $\sigma v \gamma \kappa a \dot{\theta} \eta \mu \alpha$ and $\dot{\eta} \gamma \varepsilon \mu \omega \dot{v}$ cf.: Mason 1974, 88, 148-149; on the responsibilities of an assessor see, especially: Behrends 1969, 192-226.

3 The word-building mechanism, however, is open to doubt (Beekes 2010, 47).

4 West 1979, 106. A fresh overview of the problem in Soph. OR 1264: Finglass 2018, 554-555.

${ }^{5}$ See, for instance, the text of Schol. Aristoph. Pax 80 in Groningen edition: $\mu \varepsilon \tau \varepsilon \dot{\omega} \omega \rho \circ \varsigma$ al

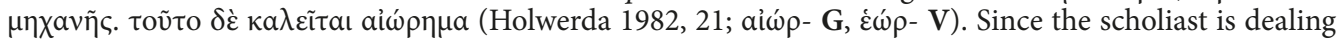
with the word $\mu \varepsilon \tau \dot{\varepsilon} \omega \rho \circ \varsigma$, the spelling $\dot{\varepsilon} \omega \operatorname{\rho } \eta \mu \alpha$ seems preferable (so Duebner 1877, 173).

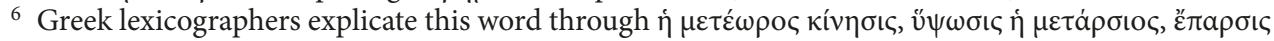

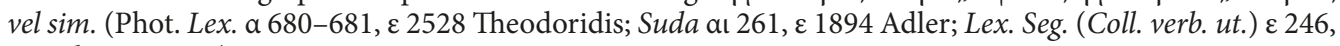
6 Bachmann; etc.). 
Since this story (63) is extant only in a longer version of the Philogelos collection, its editio princeps came as late as 1848. The editor, a prominent French Hellenist Jean François Boissonade, on facing the lexical irregularity, offered a solution to become standard

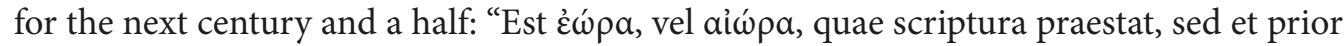
toleratur, vitis ab arboribus suspensa. $<\ldots>$ Ambulacrum arboribus praetextum fuit, quae vites sustinebant". Thus, scholastikos and his boss are walking or riding along the grapevines, suspended from tall trees. Boissonade's interpretation was adopted by all the editors, commentators and translators of the collection that we are aware of (with one exception, for which v. infra n. 29). ${ }^{8}$ It is remarkable that this unanimity went unnoticed by the lexicographers: no entry exists for éẃpa as 'vineyard' with reference to Philog. 63 either in LSJ (including both Supplements), or in Montanari; ${ }^{9}$ the meticulous thesis of Gerhard Ritter on the language of the Philogelos has no mention of it. ${ }^{10}$

A modern scholar may be of opinion that the new meaning of $\dot{\varepsilon} \omega \rho \alpha$ was made up by Boissonade ad hoc, a blend of etymology and context. Thierfelder saw it this way: "Das sah richtig Boissonade $\langle\ldots\rangle$, einen Beleg scheint es nicht zu geben". ${ }^{11}$ This judgement would, however, be premature. In both revisions of Henri Estienne's Thesaurus Graecae Linguae, which were coming hot on each other's heels in the first half of the $19^{\text {th }}$ c., the entry for aíw $\rho$ quotes an unpublished note from the papers of Gilbert Wakefield (1756-1801): "Uva pensilis. Bab. ap. Suid." ${ }^{12}$ The reference is to the verses from the fable of Babrius about a fox and grapes, as they stand in Suda al 261 Adler: $\omega \varsigma \delta^{\prime}$ oủ

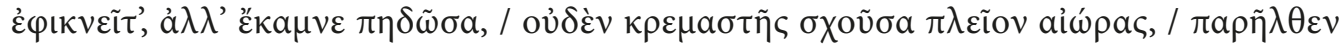

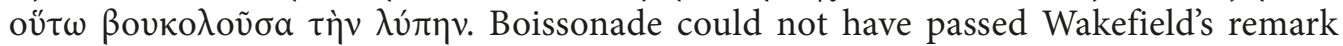
unnoticed, not only because he was a generous contributor to both the London and $\mathrm{Pa}$ risian editions of the TGL himself, but for a reason more solid. When in the early 1840s the very same Minoïdes Mynas, to whom we owe the discovery of the expanded version of the Philogelos, struck upon a manuscript of the fables of Babrius on Mount Athos, it was Boissonade who prepared the editio princeps (1844). Boissonade, thus, was the first to face what is now common knowledge that the quotations from Babrius in Suda are, at whiles, evidence of a different recension; in particular, the direct tradition of Babr. 19 lacks two of the three lines quoted above, while the fox's gnome is introduced with

7 Boissonade 1848, 280-281.

8 Eberhard 1869, 19, quoting Boissonade's note in app.; Bubb 1920, 34: "When he had gone out into

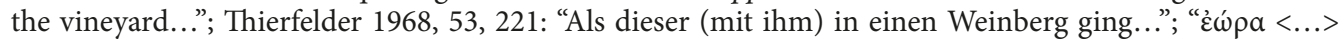
müßte hier ein Rebengehänge bezeichnen"; Cataudella 1971, 105: "Ed essendo andato questo insieme con lui in una vigna..."; Baldwin 1983, 12: "One day, they happened to go through a vineyard"; Weber-Nielsen

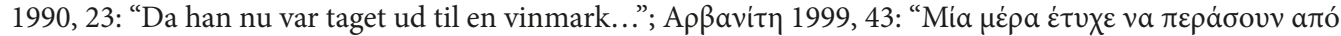

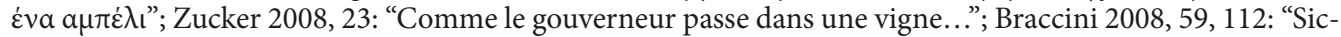
come dunque quello era uscito a passeggiare in un vigneto..."; "ad un particolare tipo di coltura della vite potrebbero effettivamente adattarsi anche le definizioni di 'innalzamento' e 'trapianto' (ü $\psi \omega \sigma \iota \varsigma$ e $\mu \varepsilon ́ \tau \alpha \rho \sigma ı \varsigma)$ che di ż́́pa vengono date in Lex. Seg."; Crompton 2010, 45: "When they've been around the vineyard..."; Vergara 2011, 85 and n.: "Il guercio, avendo imboccato una srada all'interno di un vigneto..."; "in $\dot{\varepsilon} \omega$ pa gia Boissonade aveva individuato una vite pendola"; Troca Pereira 2013, 36: "Um dia passaram por uma vinha..."; Brodersen 2016, 33: "Als der einmal in einen Weinberg kam..." Tacens consentire videtur Dawe 2000. González Suárez 2010 is inaccessible to us.

9 LSJ incorporates the Philogelos in the edition of Eberhard, albeit under a whimsical abbreviation "Hierocl. Facet.". DGE is currently one step from the entry éw

10 Ritter 1955.

11 Thierfelder 1968, 221.

12 Stephanus 1821, 1625; Stephanus 1831, 1128. 


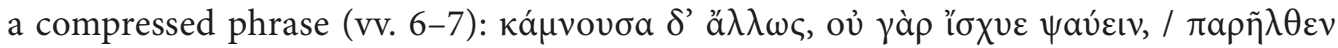

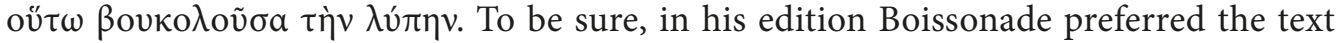
of $\mathbf{A}$; yet in a separate note he also cited the version of Suda. ${ }^{13}$ Moreover, he used the

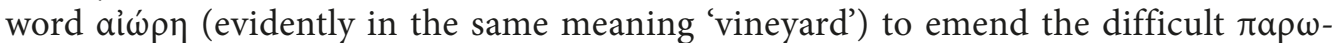

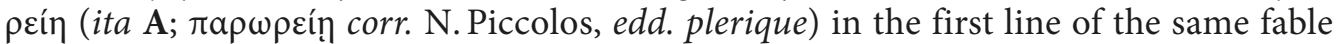

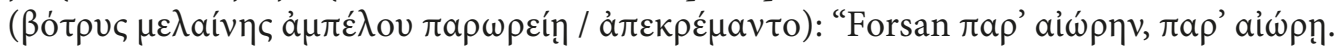
Vide n. ad v. 7". ${ }^{14}$

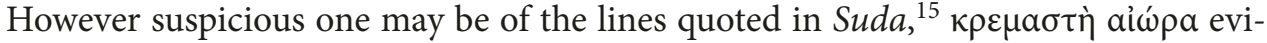
dently means 'something hanging', 'a hanging weight': the fact that grapes are meant is only prompted by the context of the fable. ${ }^{16}$ John Vaio judiciously points out that this phrase is a "frigid abstraction with a redundant epithet ('a hanging suspension')"; its verbosity is, in his opinion, ample proof that "the Suda's variant is arguably an expanded and rewritten version of the original verse". ${ }^{17}$ To mechanically apply this meaning to the text of the Philogelos - where éẃpa, according to Boissonade, should mean not even 'grapes' or 'grapevine', but 'vineyard' - proves impossible.

There is more to the story than meets the eye. Straight on the introductory details on the capacities of the characters, ex abrupto comes the narrative proper: "When he went out into a vineyard..." The goal and purpose of the provincial governor accompanied by his assessor, how they came to be among the hanging grapevines, is obscured;

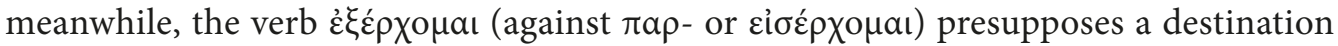
point. The only scholar to have recognised this difficulty was Thierfelder: he remarks that the vineyard could have been a matter of legal dispute and its inspection was required for passing the verdict. ${ }^{18}$ The last line of the story stands contrary to it: it is evident that the characters walk the same road past the vineyards up and down, without turning to inspect the vineyards themselves. Thus, Boissonade's interpretation seems to have no feet of its own.

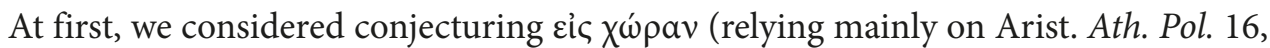

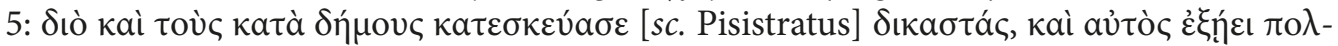

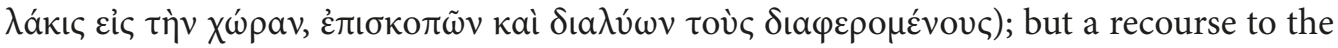
lexicons of Byzantine Greek convinced us that the text is sound.

13 "Et hic habemus reliquias alterius recensionis" (Boissonade 1844, 45, ad 19, 7).

14 Ibid., 44, ad 19, 1. This conjecture was later adopted by Lachmann and Bergk, but rejected by

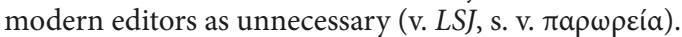

15 Cf. Luzzatto, La Penna 1986, XLI, LIV-LVI, LIX-LXII, 22. M. J.Luzzatto and A.La Penna, along with the majority of the editors, believe the lines to be a later schoolroom amplification ("imitatoris (vel imitatorum) recentioris vel Byzantinae aetatis choliambos tumido genere dicendi conflatos"), pointing out among linguistic properties alien to Babrius "aî́

16 Due to the same reason it would be risky to draw support of Boissonade's hypothesis in Geopon.V, 2,

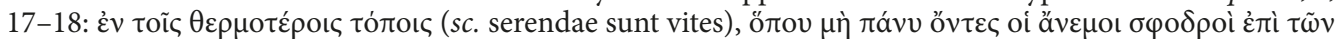

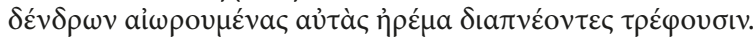

17 Vaio 2001, 47.

18 "Der richterlich fungierende $\dot{\eta} \gamma \varepsilon \mu \omega ́ v<\ldots>$ nimmt zu einer Ortsbesichtigung — der Weinberg wohl Streitobjekt - seinen Assessor mit" (Thierfelder 1968, 221). This interpretation provided an evident ground for one of the translators, who went as far as to write: "Als sie nun einmal zu einem Lokaltermin unterwegs waren..." (Löwe 1981, 20); cf. also "Having sent out for a survey one day..." (Berg 2008, ad. loc.); "Un día foron inspeccionar un parreiro...” (Seara, Soto 2016, 28). 
Indeed, in John Malalas' Chronographia $\left(6^{\text {th }} \mathrm{c}\right.$.) the verb $\dot{\varepsilon} \omega$ píoual is attested twice in the meaning 'to take a stroll': ${ }^{19}$ [1] II, 8 Thurn (=Chron. Pasch. p. 78, 15 Dindorf $\approx$ Georg. Mon. Chron. p. 17, 5 de Boor; Hercules from Tyrus discovers the secret of the purple

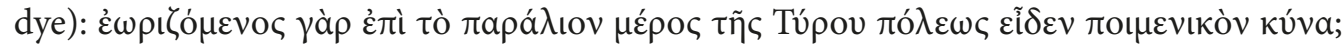

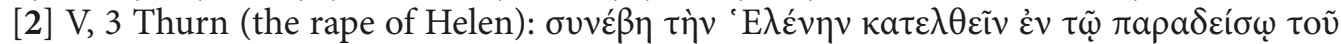

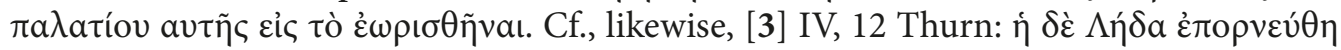

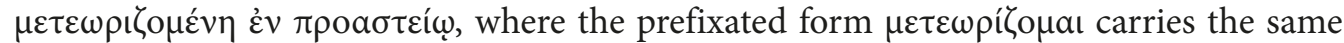
meaning. ${ }^{20}$

This pool of examples could be expanded to add an instance from the so called Iosephi Hypomnestikon, a concise libellus memorialis in Sacred and Church history dating to the end of 4 or $5^{\text {th }}$ c. A question posed in chapter 46, "Who on the pretext of kindness or piety produced dead?", has among the answers, tucked between the Serpent and Iezabel,

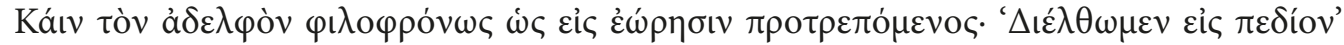

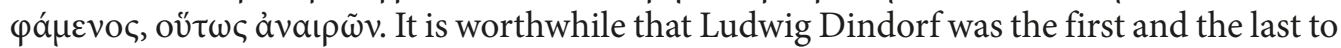
grasp the right meaning of $\dot{\varepsilon} \omega$ p $\eta \sigma \iota \varsigma$ here, as is evident from the respective entry of the Parisian TGL ("obambulatio"). ${ }^{21}$ Prior to that, Fabricius, the discoverer of Iosephi Hypomnestikon, erroneously explained it as "ad considerandum caelum",22 and Gallicciolli adopted the same meaning ("ad caelestia contemplanda"). ${ }^{23}$ As for the current critical edition, the

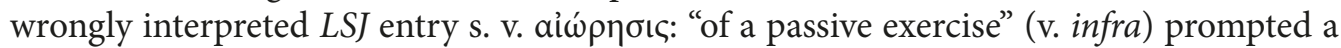

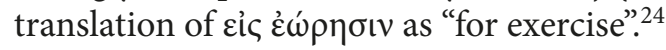

To our mind, in Philog. 63 the provincial governor accompanied by his assessor sets out of town for a walk ( $\varepsilon \dot{i} \zeta \dot{\varepsilon} \omega \rho \omega v$ ), in the course of which they happen to be passing by the vineyards on their left. ${ }^{25}$ Such an interpretation allows for both the reason and destination;

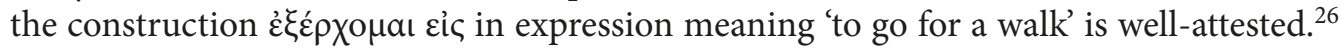
From the chronological point of view, the parallels from Iosephi Hypomnestikon and Ma-

19 Unanimously interpreted both by the editors of Malalas, and lexicographers this way: "obambulare" (Chilmead 1691, 36; L. Dindorf ap. Stephanus 1835, 2639); "to walk for amusement, to promenade" (Sophocles 1914, 551); "take a walk" (Lampe 1961, 590); "while he was wandering along the seashore"; "Helen came down into her palace garden to take a walk"; "Leda committed adultery while taking the air" (Jeffreys et al. 1986, ad locc.); "spazierengehen" (Trapp 1999, 639); "ambulo delectando me (vel moechando)" (Thurn 2000, 517); "the meaning is 'stroll', 'walk' vel sim." (Renehan 2001, 231). The same meaning seems to be at-

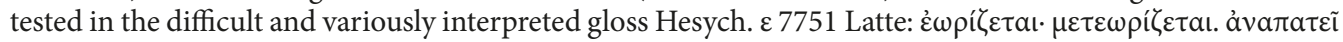
(ảva $a \tau \varepsilon \dot{\omega} \omega$ "obambulare": Sophocles 1914, 148; Lampe 1961, 115).

${ }^{20}$ Respective prefixated forms stand in the latest versions of the passages [1] (Georg. Cedren. vol. I,

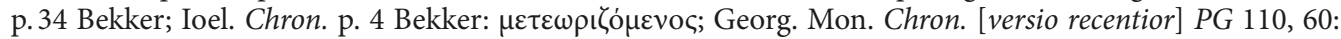

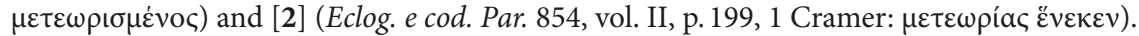

21 Stephanus 1835, 2639.

22 Fabricius 1723, 87 (2 $2^{\text {nd }}$ pag.).

23 Gallandius 1781, $22=P G$ 106, 49.

${ }^{24}$ Grant, Menzies 1996, 121. To recall the point made by C. O. Brink, "it is in effect still necessary to consult Stephanus' Thesaurus" (Brink 1963, 76).

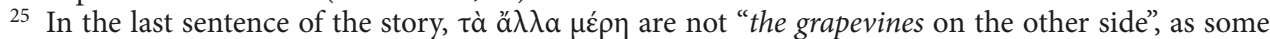
interpreters enchanted by Boissonade's ambulacrum arboribus praetextum understand it (Bubb 1920, 34; Baldwin 1983, 12; Troca Pereira 2013, 36; etc.), but, in a generic way, "the other side of the road" with all the

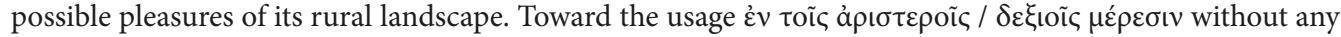
attribute in the meaning ad sinistram / dextram viae cf. Hist. Alex. Magn. $\beta$ II, 39.

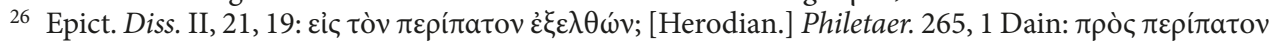

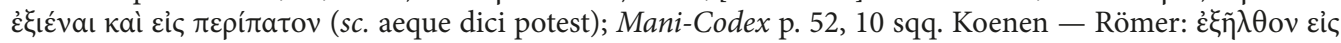

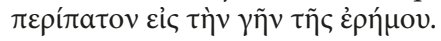


lalas leave little to be desired: our story is the sole proprietor of the hapax $\delta \varepsilon \xi$ เó $\pi \eta \rho \circ$, a closest analogy to which is found in a $6^{\text {th }}$ c. papyrus. ${ }^{27}$

The semantic development of 'to hang, to swing' > to walk about idly, aimlessly or at leasure' could well be natural: it is evident in the Eng. to hang around or in the Russ. болтаться. We would like, however, to point to an other possible origin of the meaning of $\dot{\varepsilon} \omega \rho \alpha$ we engage with here. We have so far withheld the fact that in the Empire the Greek

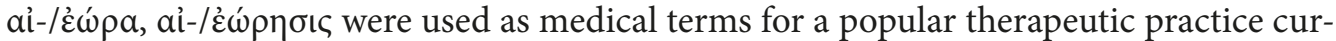
rent in Latin under the name gestatio. According to the precepts of the Methodist school of ancient medicine, a whole number of medical conditions could be preventively or effectively treated through subjecting the patient to agitation and/or swinging. The most extensive account, describing the practice - Cels. Med. II, 15, 1-3, - mentions among the basic forms of gestatio a ride in a carriage or a lectica; a boat trip or at least boarding an ancored ship was also prescribed, in simplest cases - swinging in a hammock or rocking a patient's bed. ${ }^{28}$ In principle, a therapeutic outing in a carriage or a litter suits Philog. 63 as well ${ }^{29}$ - less so for Cain and Abel in Ioseph. Hypomn. 46. This makes us prefer the generalised meaning 'a walk', assuming that the vernacular $\dot{\varepsilon} \omega \omega \rho=$ gestatio was, at some point, broadened to include any moderate physical activity. ${ }^{30}$ Indeed, although in a strict medical sense gestatio (a passive exercise, in which a patient is not flexing their muscles) and walking are in stark opposition, we can observe that in hygienic prescriptions and in

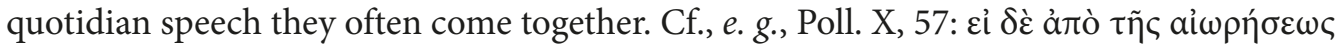

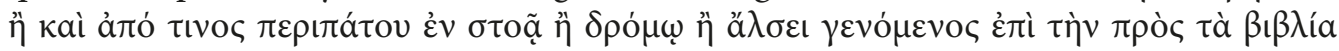

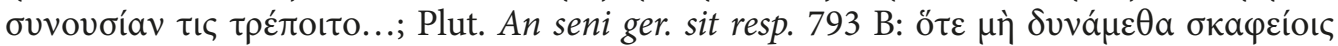

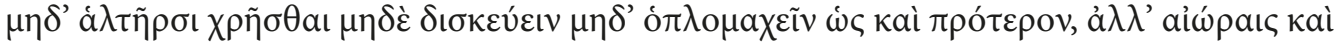

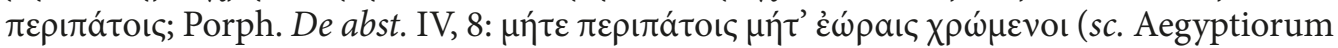

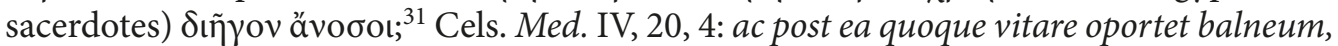
ambulationem, gestationem ceterosque corporis motus (cf. V, 28, 4d; Plin. NH XXVI, 13; XXVIII, 54; ThLL VI, 2, 1956, 69-73); Sen. Epist. 15, 7: gestatio et corpus concutit et studio non officit: possis legere, possis dictare, possis loqui, possis audire, quorum nihil ne ambulatio quidem vetat fieri; etc. $^{32}$

27 Cf. ả to an earlier $\dot{\varepsilon} \tau \varepsilon \rho \operatorname{\varphi s} \theta a \lambda \mu \circ \varsigma$ of Philog. 185) one of the Byzantine elements in the language of this collection (Ritter 1955, 89, 94, 98, 111; cf. the general conclusion on p. 112: “...Für die vorliegende sprachliche Gestalt des Philogelos fällt die Gesamt-Frühgrenze in hochbyzantinische Zeit”).

28 For the scientific grounds and social implications of gestatio v. a brilliant sketch: Gourévitch 1982, 55-65; also Ieraci Bio 2005, 771-772.

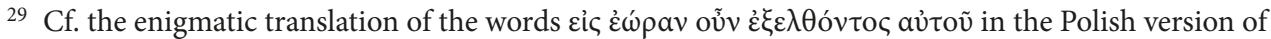
the Philogelos: "Kiedy ten wsiadł na wózek..." (Łanowski 1986, 31; the preceding phrase is quoted above, n. 1). Whether the translator had gestatio on mind, we cannot tell.

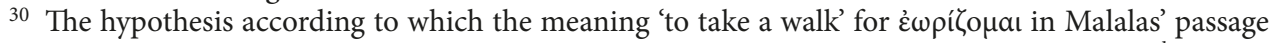
[1] sprung up due to the rethinking 'gestor', was voiced by I. F. Fischer (Fischer 1789, 194; cf. 67, $2^{\text {nd }}$ pag.).

31 The history of the text of this passage is a telling one: F.Marx defended it against an intrusion

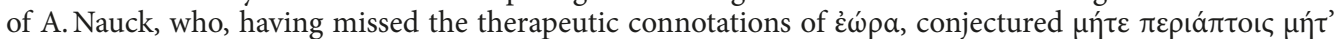
$\dot{\varepsilon} \pi \omega \delta a \tilde{c}$ (Marx 1924, 482).

32 We cordially thank the quartet of members of our postgraduate student seminar on the Philogelos (St Petersburg University, 2017/2018) - Svetlana Dubova, Natalia Kuznetsova, Alexandra Novikova, and Anastasija Pavlova: the interpretation offered here came to life in an inspiring atmosphere of seminar discussions. Tommaso Braccini, Elena Ermolaeva, Alexander Kirichenko, Daria Kondakova, Victoria Musbakhova, Arsenij Vetushko-Kalevich, and Ilya Vinitsky obliged us with bibliographical items that were out of our reach. 


\section{References}

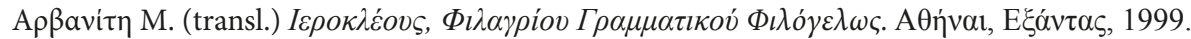

Baldwin B. (transl., comm.) The Philogelos, or Laughter-Lover. Amsterdam, J. C. Gieben, 1983.

Beekes R. Etymological Dictionary of Greek. Leiden — Boston, Brill, 2010.

Behrends O. Der assessor zur Zeit der klassischen Rechtswissenschaft. SZ 1969, 86, 192-226.

Berg W. (transl.) Philogelos, The Laugh Addict: The World's Oldest Joke Book. London, Yudu Media, 2008, http:// publishing.yudu.com/Library/Au7bv/PhilogelosTheLaughAd/resources/index.htm (01.10.2019).

Boissonade I. Fr. (ed.) Babrii Fabulae iambicae CXXIII < .. > nunc primum editae. Parisiis, Firmin Didot, 1844.

Boissonade I. Fr. (ed.) G. Pachymeris Declamationes XIII, quarum XII ineditae; Hieroclis et Philagrii gram-

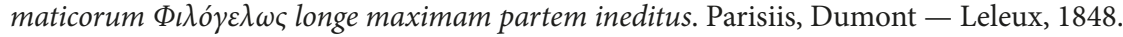

Braccini T. (ed., transl.) Come ridevano gli antichi (Philogelos). Pref. di M. Bettini. Genova, Il Melangolo, 2008.

Brink C. O. Horace on Poetry: Prolegomena to the Literary Epistles. Cambridge, CUP, 1963.

Brodersen K. (ed., transl.) Philogelos: Antike Witze. Wiesbaden, Marixverlag, 2016.

Bubb Ch. C. (transl.) The Jest of Hierocles and Philagrius. Cleveland, Rowfant Club, 1920.

Cataudella Q. La facezia in Grecia e a Roma. Firenze, Le Monnier, 1971.

Chilmead E. (ed.) Ioannis Antiocheni cognomento Malalae Historia chronica. Oxonii, E Theatro Sheldoniano, 1691.

Crompton D. (transl.) A Funny Thing Happened on the Way to the Forum: The World's Oldest Joke Book. London, Michael O'Mara, 2010.

Dawe R.D. (ed.) Philogelos. Monachi; Lipsiae, Teubner, 2000.

Duebner F. (ed.) Scholia Graeca in Aristophanem. Parisiis, Firmin Didot, 1877.

Eberhard A. (ed.) Philogelos: Hieroclis et Philagrii Facetiae. Accedit commentatio. Berolini, H.Ebeling \& C. Plahn, 1869.

Fabricius J.A. (ed., transl., comm.) Codicis pseudepigraphi Veteris Testamenti vol. 2. Accedit Iosephi veteris Christiani scriptoris Hypomnesticon, nunc primum in lucem editum. Hamburgi, Sumtu Th. Chr. Felgineri, 1723.

Finglass P. J. (ed., transl., comm.) Sophocles, Oedipus the King. Cambridge, CUP, 2018.

Fischer I. F. (ed.). Palaephati De incredibilibus. Accessere prolusiones quattuor in Palaephati fabulas cum orationibus duabus. Lipsiae, Sumtu C. Fritschii, $1789^{6}$.

Gallandius A. (ed.) Bibliotheca veterum patrum antiquorumque scriptorum ecclesiasticorum, postrema Lugdunensi multo locuplerior atque accuratior. Vol. 14. Venetiis, Ex typographia J. B. Albertii, $1781^{2}$.

González Suárez M. (ed., transl., comm.) Philógelos (El chistoso). Madrid, Ediciones Clásicas, 2010.

Gourévitch D. La gestatio thérapeutique a Rome, in: Médecins et médecine dans l'Antiquité. Éd. par G. Sabbah. Publications de l'Université de Saint-Étienne, 1982, 55-65 (Mémoires du Centre Jean Palerne 3).

Grant R.M., Menzies G.W. (ed., transl., comm.). Joseph's Bible Notes (Hypomnestikon). Atlanta, Scholars Press, 1996.

Ieraci Bio A.-M.Schaukeln, in: Antike Medizin: Ein Lexikon. Hrsg. von K.-H.Leven. München, C.H. Beck, 2005, 771-772.

Jeffreys E. et al. (transl.) The Chronicle of John Malalas. Melbourne, Australian Association for Byzantian Studies, 1986.

Holwerda D. (ed.) Scholia in Aristophanem. Vol.2, 2: Scholia vetera et recentiora in Aristophanis Pacem. Groningen, Bouma, 1982.

Lampe G. W. H. A Patristic Greek Lexicon. Oxford, OUP, 1961.

Löwe G. (transl.) Hierokles und Philagrios, Philogelos oder der Lach-Fan. Illustr. von W. Würfel. Leipzig, Koehler \& Amelang, 1981.

Luzzatto M. J., La Penna A. (ed.) Babrii Mythiambi Aesopei. Leipzig, Teubner, 1986.

Łanowski J. (transl.) Philogelos albo Śmieszek, z facecji Hieroklesa i Philagriosa. Słowem o dowcipie poprzedził J. Trzynadlowski, szatę graficzną nadał T. Łowicki. Wrocław etc., Ossolineum, $1986^{2}$.

Marx F. Critica Hermeneutica. RhM, 1924, 73, 482.

Mason J. H. Greek Terms for Roman Institutions: A Lexicon and Analysis. Toronto, Hakkert, 1974.

Renehan R. Some Supplements to the Revised LSJ Supplement. Glotta, 2001, 77, 221-243.

Ritter G. Studien zur Sprache des Philogelos: Inaug.-Diss. Zürich, Dissertationsdruckerei Leemann, 1955.

Seara M., Soto Ó. (transl., notes) Philogelos (O amante da risa). Cangos do Morrazo, Rinoceronte, 2016.

Sophocles E. A. Greek Lexicon of the Roman and Byzantine Periods. Cambridge (Mass.), Harvard University Press, 1914. 
Stephanus H. (ed.) Thesaurus Graecae linguae. Ed. nova auctior et emendatior. Vol. 1. Londini, Volpy, 1821. Stephanus H. (ed.) Thesaurus Graecae linguae. Tertio edd. K. B. Hase, G. et L. Dindorf etc. Vol. 1. Parisiis, Firmin Didot, 1831; Vol.3. Parisiis, Firmin Didot, 1835.

Tarwacka A. Obrócić prawo w żart: Instytucje prawne w zbiorze dowcipów "Philogelos". Warszawa, Wydawnictwo Naukowe Uniwersytetu Kardynala S. Wyszyńskiego, 2016.

Thierfelder A. (ed., transl., comm.) Philogelos. Der Lachfreund. München, Heimeran, 1968.

Thurn I. (ed.) Ioannis Malalae Chronographia. Berolini; Novi Eboraci, De Gruyter, 2000.

Trapp E. (Hg.) Lexikon zur byzantinischen Gräzität, besonders des 9.-12. Jahrhunderts. Bd 1, 3. Wien, Verlag der Österreichischen Akademie der Wissenschaften, 1999.

Troca Pereira R. M. (transl., notes) Hiérocles e Filágrio, Philogelos (O Gracejador). Imprensa da Universidade de Coimbra, 2013.

Vaio J. The Mythiambi of Babrius: Notes on the Constitution of the Text. Hildesheim, Olms, 2001 (Spudasmata $83)$.

Vergara G. (ed., transl., notes) $\Phi ا \lambda o ́ \gamma \varepsilon \lambda \omega \varsigma$. Cuorcontento: Barzellette greche dei nostri avi. Napoli, Graus, 2011.

Weber-Nielsen C. Philogelos eller Tossehistorier fra oldtiden. København, Holkenfeldt, 1990.

West M. L. Tragica III. BICS, 1979, 26, 104-117.

Zucker A. (transl., notes) Anonyme, Va te marrer chez les Grecs (Philogelos): Recueil de blagues grecques anciennes. Paris, Éditions Mille et une nuits, 2008.

Received: September 10, 2019

Accepted: October 27, 2019 